\title{
POTENSI BAKTERI PADA LUMPUR MANGROVE KOTA TARAKAN SEBAGAI PENGHASIL ENERGI LISTRIK BERKELANJUTAN
}

\section{POTENTIAL OF BACTERIA IN THE MANGROVE SLUDGE OF TARAKAN CITY AS A PRODUCER OF SUSTAINABLE ELECTRIC ENERGY}

\author{
Tri Paus Hasiholan Hutapea1)*, Siska Nofrida Marbun2), Encik Weliyadi2) \\ 1)Jurusan Teknologi Hasil Perikanan FPIK Universitas Borneo Tarakan \\ 2)Jurusan Manajemen Sumberdaya Perairan FPIK Universitas Borneo Tarakan \\ Jl. Amal Lama No.1,Po. Box. 170 Tarakan KAL-TARA. \\ *Email : hutapea2606@gmail.com
}

\begin{abstract}
ABSTRAK
Energi listrik merupakan energi utama yang dibutuhkan manusia. Hampir dapat dipastikan, semua teknologi yang ditemukan membutuhkan energi. MFCs ialah teknologi yang memanfaatkan mikrobial dalam medium organik untuk mengubah bahan organik menjadi energi listrik. Penelitian ini bertujuan untuk mengetahui jenis bakteri pada lumpur mangrove yang berpotensi menghasilkan energi listrik dan mengukur tegangan yang dihasilkan dari aktivitas bakteri. Penelitian ini dilakukan dengan cara mengisolasi dan mengidentifikasi bakteri dan pengukuran tegangan yang dihasilkan dari aktivitas bakteri yang terdapat pada lumpur mangrove. Hasil identifikasi bakteri diperoleh 3 (tiga) jenis isolat bakteri yang dapat hidup selama proses isolasi yaitu Aeromonas sp, Actinobacilus sp dan Enterobacteria sp. Hasil penelitian selama 28 hari dilakukan pengukuran tegangan listrik pada MFCs. Tegangan listrik yang dihasilkan mencapai puncak produksi tegangan listrik pada hari ke-3 yaitu $243 \mu \mathrm{V}$ pada lumpur mangrove.
\end{abstract}

Kata kunci : Microbial Fuel cells (MFCs), Bakteri, Energi terbarukan

\section{ABSTRACT}

Electrical energy is the main energy needed by humans. Almost certainly, all the technologies found require this energy. MFCs are technologies that utilize microbials in organic mediums to convert organic materials into electrical energy. This study aims to determine the type of bacteria in mangrove mud that potentially generate electrical energy and measure the voltage generated from bacterial activity. This research was conducted by isolating and identifying bacteria and stress measurement resulting from bacterial activity found in mangrove sludge. The results of the research During 28 days of measurement of electrical voltage on MFCs. The result of bacteria identification obtained 3 (three) types of bacterial isolates that can live during the isolation process of Aeromonas sp, Actinobacilus sp and Enterobacteria sp. The resulting electric voltage reached the peak of electricity voltage production on the 3 rd day of $243 \mu V$ in mangrove sludge.

Keywords: Microbial Fuel cells (MFCs), Bacteria, Electrical energy 


\section{PENDAHULUAN}

Energi listrik merupakan energi utama yang dibutuhkan manusia. Hampir dapat dipastikan, semua teknologi yang ditemukan membutuhkan energi ini. Seakan tidak dapat dipisahkan dari kehidupan manusia, energi listrik secara tidak sadar sudah menjadi kebutuhan primer yang harus dipenuhi setiap saat. Pengembangan untuk mendapatkan sumber energi listrik terus dilanjutkan agar ketersediaan listrik dapat terjaga. Salah satu cara pembangkit energi listrik alternatif yang belakangan ini marak dikembangkan oleh para ahli ialah untuk menghasilkan energi listrik yaitu Microbial Fuel Cells (MFCs) dan diharapkan menjadi teknologi yang menjanjikan untuk memenuhi kebutuhan listrik.

MFCs ialah teknologi yang memanfaatkan mikrobial dalam medium organik untuk mengubah bahan organik menjadi energi listrik. Sifat mikroba yang dapat mendegradasi medium organik (enrichment media) pada MFCs menghasilkan ion elektron dan proton sehingga ion-ion inilah yang menghasilkan perbedaan potensial listrik. Bakteri yang dimanfaatkan untuk membangkitkan energi adalah dari jenis bakteri yang melakukan aktivitas reaksi oksidasi reduksi. Bakteri ini biasanya hidup didalam tanah atau lumpur (Strik et al., 2008). Potensi keberadaan bakteri ini pun sangat besar pada lumpur hutan mangrove.

Lumpur hutan mangrove merupakan substrat untuk beraktivitasnya jutaan bakteri. Hal ini didukung dengan kelimpahan bahan organik dilumpur hutan mangrove yang salah satunya berasal dari serasah tumbuhan mangrove (Yulma, 2015). Aktivitas bakteri biasanya mengalami reaksi oksidasi dan reduksi yang akan menghasilkan nutrient (Dwi, 2004) yang terdapat pada lumpur hutan mangrove. Kecepatan oksidasi sangat ditentukan oleh peran dari bakteri pengoksidasi dan dalam kondisi reduksi, sangat ditentukan oleh aktivitas bakteri pereduksi. Dengan adanya reaksi oksidasi reduksi, maka akan adanya lompatan elektron. Elektron yang bergerak dapat diukur dalam bentuk tegangan. Sehingga dalam penelitian ini akan diukur tegangan yang terjadi dari aktivitas bakteri dalam lumpur hutan mangrove.

Hutan mangrove yang digunakan sebagai tempat penelitian adalah hutan mangrove yang berada di Kota Tarakan, Kalimantan Utara. Hal ini akan menjadi sangat penting karena ketersediaan sumber energi listrik yang ada di kota Tarakan semakin terbatas. Seringnya pemadaman listrik yang dilakukan oleh PT PLN kota Tarakan menyebabkan keresahan masyarakat Kota Tarakan. Diharapkan melalui penelitian ini akan menjadi solusi dari permasalahan ketersedian energi listrik di Kota Tarakan Kalimantan Utara

\section{METODE PENELITIAN}

\section{Peralatan}

Alat yang digunakan dalam penelitian ini yaitu botol uc $140 \mathrm{ml}$, inkubator, gelas objek, jarum ose, mikropipet, tabung reaksi, aluminium foil, autoklaf, laminary air flow (aliran udara), timbangan analitik, lampu bunsen, cawan petri, speader, timbangan analitik, multimeter, dan solder.

\section{Bahan}

Bahan yang digunakan dalam penelitian ini yaitu lumpur mangrove, motility indol ornithin (MIO), larutan katalase $\left(\mathrm{H}_{2} \mathrm{O}_{2}\right.$ $3 \%$ ), trypticase soy agar (TSA), larutan kalium hidroksida (KOH 3\%), paraffin, stripe oksidase (kertas oksidasi), larutan respirasi dan karbohidrat $(\mathrm{O} / \mathrm{F})$, larytan glukosa, alkohol 70\%, aquades, pewarnaan gram, lilin, kabel listrik, logam timah, dan plat besi. 


\section{Prosedur Penelitian \\ Isolasi Bakteri}

Isolasi bakteri dilakukan dengan cara menimbang lumpur mangrove sebanyak 5 gram. Selanjutnya dilakukan tahap pengenceran. Pengenceran lumpur mangrove mencapai tingkat 10-7 menggunakan botol uc yang berukuran 140 ml sebanyak 7 botol yang telah disterilkan dan diberi label 10-1 - 10-7. (Hadioetomo, 1993; Cappuccino dan Sherman, 1996).

\section{Identifikasi Bakteri Lumpur Mangrove}

\section{Uji Pewarnaan Gram}

Objek gelas dibersihkan dengan alkohol $70 \%$ dan diberi aquades, kemudian diambil sedikit biakan bakteri menggunakan jarum ose, diratakan pada kaca objek dan diletakan pada laminari sampai kering, setelah kering ditetesi dengan larutan Kristal Violet (Gram A), dan didiamkan selama 1 menit, lalu dicuci dengan air mengalir dan dikeringkan. Selanjutnya ditetesi dengan larutan Yodium (Gram B) dan dibiarkan selama 1 menit, lalu dicuci dengan air mengalir dan dikeringkan. Kemudian ditetesi Acetone Iodine (Gram C) dan dibiarkan selama 1 menit, lalu dicuci dengan air mengalir dan dikeringkan. Setelah itu ditetesi dengan larutan sarafin (Gram D), kemudian dicuci dengan air mengalir dan dikeringkan.

2. Uji Utama (KOH 3\%, Katalase (H2O2) $3 \%$ dan Oxidase)

\section{a. Uji KOH $3 \%$ (Kalium Hidroksida)}

Objek gelas dibersihkan dengan alkohol $70 \%$ dan ditetesi $\mathrm{KOH} \mathrm{3 \%}$ pada objek gelas, kemudian diambil sedikit biakan bakteri menggunakan jarum ose dan dicampurkan dengan $\mathrm{KOH} 3 \%$.

\section{b. Uji $\mathrm{H}_{2} \mathrm{O}_{2}$ (Katalase)}

Objek gelas dibersihkan dengan alkohol $70 \%$ dan ditetesi katalase $\left(\mathrm{H}_{2} \mathrm{O}_{2}\right)$ kemudian diambil sedikit biakan bakteri menggunakan jarum ose dan dicampurkan dengan katalase $\left(\mathrm{H}_{2} \mathrm{O}_{2}\right)$.

\section{c. Uji Oksidase}

Biakan atau isolat bakteri yang murni diambil dengan menggunakan jarum ose steril, Isolat bakteri tersebut kemudian diletakkan pada kertas baktiden oksidase. Setelah itu didiamkan selama 20-60 menit dan diamati perubahannya

\section{Uji Lanjut (O/F , Glukosa dan Mio) a. $\mathrm{Uji} \mathrm{O} / \mathrm{F}$}

Inokulasi bakteri pada media O/F dilakukan secara aseptis dengan menusukan jarum ose steril yang mengandung isolat bakteri lurus kedalam 2 tabung / media O/F. Yang satu ditutup dengan parafin oil dan yang satunya lagi dibiarkan tanpa parafin oil. Kemudian media $\mathrm{O} / \mathrm{F}$ yang telah diinokulasi bakteri selanjutnya diinkubasi dengan temperature $30^{\circ} \mathrm{C}$.

\section{b. Uji Glukosa}

Pengujian gula-gula (Glukosa) dilakukan dengan cara menginokulasikan bakteri secara aseptis kedalam media gula-gula. Inokulasi dilakukan dengan menggunakan ose steril kemudian dicampurkan pada media gula-gula (Glukosa). Media glukosa yang telah diinokulasi selanjutnya diinkubasi dengan temperature $30^{\circ} \mathrm{C}$.

\section{c. Uji Motility Indole ornithine (MIO)}

Untuk menguji Motility biakan atau isolat bakteri yang murni diambil sedikit dengan menggunakan jarum ose steril, kemudian menusuk lurus sampai bawah kemedia MIO. Selanjutnya diinkubasi media MIO dengan temperatur $30^{\circ} \mathrm{C}$.

\section{Pengukuran tegangan yang dihasilkan oleh aktivitas bakteri}

\section{Pembuatan media aktivitas bakteri (Elektroda)}

Plat besi yang digunakan sebagai media ada 2 yaitu sebagai anoda (+) dan katoda (). Pembuatan media untuk bakteri beraktivitas dilakukan dengan cara membakar parafin. Pembakaran dilakukan secara perlahan sampai menghasilkan 
karbon kemudian plat besi diletakkan diatas pembakaran parafin agar karbon yang dihasilkan dapat menyelimuti permukaan plat besi. Pada tahap awal plat besi yang digunakan berukuran $8 \mathrm{~cm} \times 6$ $\mathrm{cm}$ dengan ketebalan $0,5 \mathrm{~mm}$. Plat besi yang telah terlapis karbon kemudian disambung dengan 2 buah kabel listrik. Pembuatan media tumbuh bakteri sebanyak 10 plat besi.

\section{Pengukuran tegangan}

Pengukuran tegangan dilakukan secara langsung di lumpur Mangrove. Media tumbuh bakteri yang telah dibuat, ditanam didalam lumpur hutan Mangrove sedalam $30 \mathrm{~cm}$. Setelah ditanam, media tumbuh bakteri dibiarkan selama 28 hari. Dilakukan pengukuran tegangan yang dihasilkan secara berkala pada hari ke 3, 5, 7, 14, 21, 28 menggunakan alat multimeter pada sepuluh media tumbuh bakteri.

\section{HASIL DAN PEMBAHASAN}

Hasil identifikasi bakteri diperoleh 3 (tiga) jenis isolat bakteri yang dapat hidup selama proses isolasi yaitu Aeromonas sp, Actinobacilus sp dan Enterobacteria sp. Hasil karakterisasi ketiga bakteri tersebut ditelaah menggunakan pencocokan uji dengan panduan identifikasi bakteri berdasarkan Bergey's Manual of Determinative Bacteriology, 9th Ed (Holt et al.. 1994).

Bakteri Aeromonas sp. bersifat Gram negatif dari adanya reaksi oksidase positif, karakteristik berbentuk batang pendek, bersifat aerob dan fakultatif anaerob, tidak berspora, motil, mempunyai satu flagel, hidup pada kisaran suhu $20-30^{\circ} \mathrm{C}, \mathrm{pH} 4.7-$ 11. Bakteri ini mampu memfermentasikan beberapa gula seperti glukosa, fruktosa, maltose, dan trehalosa. Aeromonas sp termasuk bakteri gram negatif dan berbentuk bulat bersifat motil dan dapat hidup pada kondisi aerob. Suhu optimum untuk pertumbuhannya yaitu $22^{\circ} \mathrm{C}$, tetapi sebagian besar bakteri ini tumbuh baik pada suhu $37^{\circ} \mathrm{C}$ (Holt, et al., 1994). Bakteri ini mampu memanfaatkan senyawa gula seperti glukosa, maltosa, dan sakarosa yang dikatabolisme dengan memproduksi asam dan menghasilkan gas.

Bakteri Actinobacillus sp. merupakan gram negatif yang memiliki kemampuan dalam mendegradasi fruktosa, laktosa, selulosa, kitin, maltose dan glukosa (Lamid et al., 2006). Bakteri bersifat anaerob dan aerob yang mampu mempermentasikan karbohidrat dan menghasilkan enzim yang mencerna substrat eksternal dan memanfaatkan bahan organik sebagai sumber karbon dan energi. Bakteri Actinobacillus sp. mampu hidup pada $\mathrm{pH}$ di atas 6 (Lally et al., 1989). Actinobacillus sp. termasuk dalam kelompok bakteri gram negatif, sel berbentuk bulat dan bersifat non motil (Holt, et al., 1994). Bakteri ini umumnya hidup pada kondisi anaerob fakultatif dan mampu memfermentasi karbohidrat. Actinobacillus sp. memiliki kemampuan dalam membentuk spora sehingga sangat menguntungkan bagi bakteri tanah terkait dengan kondisi lingkungannya yang selalu berubah dan tidak menguntungkan (Waluyo, 2007).

Bakteri Enterobacteria sp. merupakan bakteri gram negatif berbentuk batang. Enterobacteria sp. merupakan bakteri yang tersebar secara luas di alam. Bakteri ini terdapat pada air, tanah, tumbuhtumbuhan. Bakteri ini tidak dapat membentuk spora bakteri dari keluarga Enterobacteriaceae. Bakteri ini mampu memfermentasikan glukosa, nitrat berubah menjadi nitrit, tumbuh pada suhu $25-45^{\circ} \mathrm{C}$ dan suhu optimum hidupnya yaitu $37 \mathrm{oC}$ dan pH 6,8 (Farmer et al., 1980). Enterobactriaceae merupakan kelompok gram negatif, berbentuk batang, memfermentasi glukosa menjadi asam atau asam dan gas, katalase (+), Motil dan ada yang non motil, oksidase (+), sering di jumpai pada permukaan eksternal atau internal dari tubuh sebagai infeksi yang 
dapat menyerang system kekebalan tubuh manusia (Jawetz, 2013). Anggota Enterobacteriaceae kebanyakan juga dapat mengubah nitrat menjadi nitrit, walaupun ada penegecualian (misalnya photorhadus). Enterobacteriaceae kebanyakan memiliki flagel digunakan untuk bergerak, tetapi ada juga kelompok yang non-motil. Enterobacteriaceae merupakan nonspora dan membentuk reaksi katalase bervariasi, dalam pertumbuhannya Enterobacteriaceae kurang atau sedikit memerlukan NaCI.
Produksi tegangan listrik Microbial Fual Cell (MFCs)

Produksi tegangan listrik yang dihasilkan merupakan hasil kegiatan dari mikroorganisme pada sedimen yang mengkonversi bahan organik menjadi energi listrik. Pengukuran tegangan listrik pada MFCs dilakukan selama 28 hari. Pengukuran tegangan listrik yang dihasilkan selama penelitian dapat dilihat pada Tabel 1 dan Gambar 2.

Table 1. Hasil Pengukuran tegangan listrik

\begin{tabular}{|c|c|c|c|c|c|c|c|c|c|c|}
\hline Plat besi & Hari ke-1 & Hari ke-3 & Hari ke-5 & Hari ke-7 & $\begin{array}{l}\text { Hari } \\
14\end{array}$ & ke- & $\begin{array}{l}\text { Hari } \\
21\end{array}$ & ke- & $\begin{array}{l}\text { Hari } \\
28\end{array}$ & ke- \\
\hline $\bar{A}$ & 0 & 243 & 192 & 57 & & 39 & & 14 & & 0 \\
\hline B & 0 & 138 & 76 & 63 & & 47 & & 20 & & 0 \\
\hline $\mathrm{C}$ & 0 & 175 & 120 & 95 & & 56 & & 0 & & 0 \\
\hline D & 0 & 87 & 47 & 24 & & 27 & & 0 & & 0 \\
\hline E & 0 & 142 & 90 & 18 & & 21 & & 0 & & 0 \\
\hline $\mathrm{F}$ & 0 & 196 & 164 & 92 & & 53 & & 8 & & 0 \\
\hline G & 0 & 183 & 152 & 74 & & 42 & & 3 & & 0 \\
\hline $\mathrm{H}$ & 0 & 66 & 27 & 33 & & 16 & & 0 & & 0 \\
\hline I & 0 & 210 & 187 & 76 & & 43 & & 0 & & 0 \\
\hline $\mathrm{J}$ & 0 & 84 & 32 & 38 & & 24 & & 7 & & 0 \\
\hline RATA-RATA & 0 & 152.4 & 108.7 & 57 & & 36.8 & & 1.6 & & 0 \\
\hline
\end{tabular}

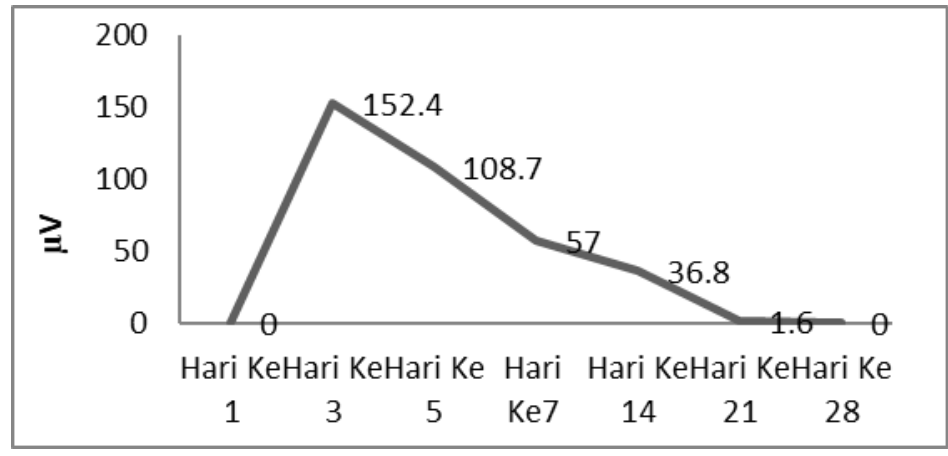

Gambar 1. Rata-rata produksi tegangan listrik MFCs

Hasil pengukuran tegangan listrik dihari pertama yaitu sebesar $0 \mu \mathrm{V}$, hal ini disebabkan karena belum terjadinya oksidasi reduksi pada plat besi yang dilakukan oleh bakteri.

Produksi tegangan listrik mencapai puncak pada hari ketiga dan menjadi tegangan maksimal MFCs yaitu sebesar $243 \mu \mathrm{V}$. Awal pengukuran, tegangan listrik yang dihasilkan meningkat drastis hingga mencapai puncak produksi kemudian tegangan listrik secara bertahap menurun. Tegangan listrik yang dihasilkan meningkat sebanding dengan jumlah 
bakteri yang hidup pada elektroda. Hasil pengukuran tegangan listrik dihari terakhir yaitu sebesar $0 \mu \mathrm{V}$, hal ini disebabkan karena karbon pada plat besi (elektroda) telah habis. Penurunan tegangan listrik menjelang akhir pengukuran disebabkan bakteri yang terdapat di sekitar elektroda berkurang.

Mikroorganisme adalah organisme yang berukuran sangat kecil (mikroskopis), termasuk bakteri, yeasts, jamur benang (mold) dan bakteria, yang mampu berperan di berbagai proses alami dan bioteknologi, termasuk MFCs (Microbial Fuel Cells). Pertumbuhannya pada umumnya sangat cepat sehingga dapat menghasilkan komunitas mikroorganisme dalam jumlah yang besar. Sejumlah bakteri exoelectrogen dilaporkan membentuk struktur khusus yang dinamakan nanowire. Nanowire tersebut diperkirakan berfungsi sebagai penghantar elektron. Sejumlah mikroorganisme dapat digunakan untuk menghasilkan aliran listrik melalui MFCs. MFCs digunakan dan didesain untuk menghasilkan energi listrik secara elektrokimia. Proses oksidasi pada anoda dan proses reduksi pada katoda mampu menghasilkan energi listrik. MFCs tidak memerlukan katalis metal pada anoda, melainkan mikroorganisme yang secara biologis mampu mengoksidasi materi organik dan mentransfer elektron ke anoda. Sementara itu, proton dipisahkan dan ditransfer ke katoda. Oleh karena itu, dapat dikatakan bahwa semua materi yang dapat dibiodegradasi dapat digunakan sebagai MFCs. Bakteri pada MFCs tidak secara langsung mentransfer elektron yang dihasilkan ke aseptor elektron terminalnya, melainkan menyalurkan ke elektroda (anoda). Elektron-elektron kemudian dikonduksikan mendekati katoda sehingga menghasilkan energi listrik. Elektron dihasilkan oleh bakteri dari senyawa tersebut dan ditransfer ke anoda (terminal negatif), kemudian mengalirkannya ke katoda (terminal positif). Elektron yang dihasilkan oleh bakteri dapat ditransfer ke anoda melalui mediator elektron, dan dengan bantuan membran tertentu atau nanowire. Pada katoda terjadi proses reduksi, senyawa yang mengalami reduksi adalah air. Air adalah substansi kimia dengan rumus kimia $\mathrm{H}_{2} \mathrm{O}$. Satu molekul air tersusun atas dua atom hidrogen yang terikat secara kovalen pada satu atom oksigen. Air bersifat tidak berwarna, tidak berasa dan tidak berbau pada kondisi standar, yaitu pada tekanan $100 \mathrm{kPa}$ (1 bar) and temperatur $273,15 \mathrm{~K}\left(0^{\circ} \mathrm{C}\right)$. Zat kimia ini merupakan suatu pelarut yang penting, yang memiliki kemampuan untuk melarutkan banyak zat kimia lainnya, seperti garam-garam, gula, asam, beberapa jenis gas dan banyak macam molekul organik. Air sering disebut sebagai pelarut universal karena air melarutkan banyak zat kimia. Dalam bentuk ion, air dapat dideskripsikan sebagai sebuah ion hidrogen $(\mathrm{H}+)$ yang berasosiasi (berikatan) dengan sebuah ion hidroksida (OH-). Reaksi reduksi air dapat dilihat melalui persamaan :

$$
2 \mathrm{H}_{2} \mathrm{O}_{(\mathrm{g})}+2 \mathrm{e} \quad \longrightarrow \quad \mathrm{H}_{2(\mathrm{~g})}+2 \mathrm{OH}_{(\mathrm{aq})}^{-}
$$

Reaksi oksidasi reduksi (Redoks) adalah reaksi yang didalamnya terjadi perpindahan elektron secara berurutan dari satu spesies kimia ke spesies kimia lainnya, yang sesungguhnya terdiri atas dua reaksi yang berbeda, yaitu oksidasi (kehilangan elektron) dan reduksi (memperoleh elektron). Reaksi ini merupakan pasangan, sebab elektron yang hilang pada reaksi oksidasi sama dengan elektron yang diperoleh pada reaksi reduksi. Masing-masing reaksi (oksidasi dan reduksi) disebut reaksi paruh (setengah reaksi), sebab diperlukan dua setengah reaksi ini untuk membentuk sebuah reaksi dan reaksi keseluruhannya disebut reaksi redoks.

Pola produksi tegangan listrik pada MFCs menunjukkan kesamaan dengan beberapa penelitian serupa seperti, penelitian yang 
menggunakan sedimen sungai sebagai substrat dalam MFCs. Hasil penelitian menghasilkan tegangan maksimal sebesar 29,3 $\mathrm{mA} / \mathrm{m} 2$, kemudian mengalami penurunan secara bertahap seiring waktu menurut (Hong et al., 2010). Perbedaan tegangan listrik yang dihasilkan disebabkan oleh jenis air, jumlah bahan organik yang terkandung dalam sedimen dan berbagai kondisi operasi lainnya. Kinerja MFCs dipengaruhi oleh kecepatan degradasi substrat, kecepatan transfer elektron dari bakteri ke anoda, transfer proton dalam larutan, aktivitas mikroba, dan substrat yang digunakan. Analisis data menggunakan uji statistik One sample Ttest untuk mengetahui perbedaan hasil pengujian tegangan listrik yang diukur sebanyak 7 kali. Setiap pengukuran dilakukan 10 kali karena terdapat 10 plat besi. Berdasarkan uji statistik menggunakan One sample T-test, diperoleh nilai probabilitas sebesar 0.724 atau $\mathrm{P}>0,05$. Hal ini menggambarkan bahwa tidak terdapat perbedaan yang signifikan terhadap hasil pengujian tegangan listrik yang diukur sebanyak 7 kali pengukuran selama 28 hari.

\section{KESIMPULAN}

Hasil identifikasi bakteri diperoleh 3 (tiga) jenis bakteri yang dapat hidup selama proses isolasi yaitu Aeromonas sp, Actinobacilus sp dan Enterobacteria sp. Selama 28 hari dilakukan pengukuran tegangan listrik pada MFCs. Tegangan listrik yang dihasilkan mencapai puncak produksi tegangan listrik pada hari ke-3 yaitu $243 \mu \mathrm{V}$ pada lumpur mangrove dan secara bertahap mengalami penurunan.

\section{DAFTAR PUSTAKA}

Bernhard, A. (2010). Nitrogen is one of the primary nutrients critical for the survival of all living organisms. Although nitrogen is very abundant in the atmosphere, it is largely inaccessible in this form to most organisms. This article explores how nitrogen becomes avai. Nature Education Knowledge, 2(2), 1-8.

Cappuccino, J. G dan N. Sherman.1996. Microbiology A Laboratory Manual. Rockland Community College Suffern. New York.

Cowan and Steel's. 1993. Manual for the identification of medical bacteria. 3rd Edition. Cambridge University Press. New York. pp. 21-25.

Dwi, A. (2004). Effect of $\mathrm{pH}$ and organic substrate on growth and activities of ammonia-oxidizing bacteria. Biodiversitas, Journal of Biological Diversity, 5(2), 43-47. https://doi.org/10.13057/biodiv/d0502 01

Farmer JJ III, Abury MA, Hickman FW, Brenner DJ, the Enterobacteriaceae Study Group (USA)(1980). "Enterobacter sakazakii: a new species of "Enterobacteriaceae"isolated from clinical specimens". Int J Syst Bacteriol 30:569-84.

Hadioetomo, R., S. 1993. Mikrobiologi Dasar Dalam Praktek : Teknik dan Prosedur Dasar Laboratorium. PT Gramedia Pustaka Utama. Jakarta.

Holt, J. H., Krieg, N. R., Sneath, P. H. a., Staley, J. T., \& Williams, S. T. (1994). Bergey's manual of determinative bacteriology ninth edition. European Journal of Paediatric Neurology: EJPN: Official Journal of the European Paediatric Neurology Society, 13(6),560.https://doi.org/10.1016/j.ejp n.2008.10.006

Hong, S.W., Hyung J.K., Yong S.C. \& Tai H.C. (2010). Alteration of sediment organic matter in sediment microbial fuel cell technology.EnvirontmentalPolution.T ersediapada:http://ocean.kisti.re.kr/do wnfile/volume/chemical/JCGMCS/20 10/v31n7/JCGMCS_2010_v31 
n7_2025.pdf(diakses pada 8 Maret 2014)

Jawet, G. F., Carroll, K. C., Butel, B., Morse, S. A., \& Mietzner, T. (2013). Medical Microbiology. Jawetz, Melnick, \& Adelberg's Medical Microbiology.

https://doi.org/10.1017/CBO97811074 15324.004

Lally, E. T., Golub,E. E., Kieba, I. R., Taichman, N. S., Rosenbloom, J. C., Gibson, C.W. \& Demuth, D.R. (1989). Analysis of the Actinobacillus actinomycetemcomitans leuko-toxin gene. J Biol Chem

Lamid, M., S. Chuzaemi, N. T. Puspaningsih dan Kumartono. 2006. Inokulasi Bakteri Xilanolitik Asal Rumen Sebagai Upaya Peningkatan
Nilai Nutrisi Jerami Padi. Universitas Airlangga. Surabaya.

Strik, B., D. P. B. T., M., H. (Bert) H. V, H., S. J. F., \& N., B. C. J. (2008). Green electricity production with living plants and bacteria in a fuel cell. International Journal of Energy Research, 32(9), 870-876. https://doi.org/10.1002/er.1397

Waluyo L.2007.Mikrobiologi Umum. UMM Press. Malang

Yulma, Ihsan, B., Sunarti, S., Malasari, E., Wahyuni, N., \& Mursyban, M. (2017). Identifikasi Bakteri Pada Serasah Daun Mangrove yang Terdekomposisi di Kawasan Konservasi Mangrove dan Bekantan (KKMB) Kota Tarakan. Journal of Tropical Biodiversity Biotechnology,2(1),28.https://doi.org/ 10.22146/jtbb. 27173 